\title{
Penataan Perkotaan dan Marginalisasi Sektor Informal
}

\author{
Sudarsono
}

The informal sector denotes a sector that plays important role in term of Indonesian economical building. According to Biro Pusat Statistik, informal sector supports about $74 \%$ toward vacation in 1985, decreases $72 \%$ in 1990, and $65 \%$ in 1998 . These decreases mean that informal sector constitutes eccept dominant young worker. Instead, after economy crises, it is predicted the acceptance of young workers tend to increase. Büt, this important role, the discourse about informal sector more tends to show the problem than to solve it. This happens because of the lack of the correct limitation of informal sector.

Kata kunci: pembangunan, berkelanjutan, sektor informal

Dembangunan perkotaan selalu dikaitkan dengan suatu kebijakan kepala daerah atau penguasa yang sedang melaksanakan penataan daerahnya, namun selalu juga muncul masalah baru, yang terkait dengan sektor-sektor ekonomi yang akan menopang keberlangsungan kota itu sendiri.

Tulisan ini akan berangkat dari kebijakan tentang sektor informal yang selalu mengikuti perkembangan pembangunan ekonomi, sektor informal ini ditimbulkan oleh beragamnya kriteria yang dapat digunakan untuk dapat menentukan apakah suatu fenomena perkotaan disebut informal atau tidak, antara lain dari sudut legal - illegal (diakui hukum atau tidak), regulated unregulated (diatur oleh pemerintah atau tidak diatur), terdaftar - atau tidak terdaftar, permanen atau tidak permanen, memiliki domisili yang jelas atau tidak mempunyai domisili yang jelas, membayar pajak atau tidak membayar pajak dan lain-lain.

Misalnya, sebuah fenomena (kegiatan atau keberadaan) perkotaan bisa saja memiliki domisili yang jelas, terdaftar dan membayar sejenis retribusi atau iuran kepada pemerintah, namun masih tertap dikategorikan sebagai informal karena tidak memiliki status legal yang jelas.

Ketidakjelasan batas formal - informal juga disebabkan oleh banyaknya interaksi dan keterkaitan antara kegiatan informal dan formal. Konsep "ends-means" dari Hemando de Soto, misalnya, mengatakan bahwa kegiatan informal itu dicirikan oleh tujuan ("ends") yang legitimate - karena untuk memenuhi kebutuhan pokok-tetapi dengan cara-cara ("means") yang tidak legitimate, karena tidak memenuhi tata-aturan formal.

Oleh karena itu, cara pandang yang lebih tepat terhadap dualisme formal-informal adalah bukan dengan melihatnya 
sebagai sebuah dikotomi (formal atau informal) tetapi sebagai sebuah kontinum (continuum), di mana terdapat daerah abu-abu yang sangat luas diantara dua posisi ekstrim; sangat "formal" (memiliki semua ciri-ciri formal) dan "sangat informal" Imemiliki semua ciri-ciri informal). Sudut pandang seperti ini pun masih seringkali dipertanyakan karena pada sisi "sangat informal" terdapat berbagai kegiatan yang bisa dikategorikan kriminal, yang tentunya memang harus diberantas.

Namun terlepas dari berbagai ketidakjelasan di atas yang umumnya bersifat akademik - permasalahan sektor informal sangat nyata dirasakan di kota-kota di negara berkembang pada umumnya dan di negara maju pada kasus-kasus tertentu. Di Indonesia, sektor informal perkotaan bahkan menjadi tumpuan kehidupan yang semakin besar sejak terjadinya krisis ekonomi yang dimulai pada tahun 1987. Atas dasar inilah, beramai-ramai menyoroti sektor informal perkotaan.

Mengikuti kategorisasi DE Soto, catatan tentang sektor informal kali ini terbagi dalam tiga kelompok utama, yaitu: 1. Sub sektor perumahan dan pertanahan informal, misalnya permukiman spontan atau tidak terencana; 2 . Sub sektor transportasi informal, misalnya becak atau ojek dan 3. Sub sektor perdagangan informal, misalnya pedagang kaki lima (PKL) atau asongan. Ismet Belgawan Harun mengulas fenomena terjadinya pasar.tanah perkotaan di pinggiran kota metropolitan dan menyarankan pengakuan oleh pemerintah terhadap fenomena ini. Pengakomodasian hal ini dalam proses pengembangan lahan perkotaan - atau yang disebut "Communitybased urban land market"-diharapkan dapat menghasilkan tata ruang yang lebih baik tanpa mengurangi tingkat keterjangkauannya.
Sementara itu; Bambang Susantono menyeroti tentang keberadaan transportasi informal dan mengusulkan perlunya reposisi angkutan informal melalui pendekatan pasar transportasi yang partisipatif dan berbasis komunitas, sehingga dapat dicapai "triplewin solution" di mana pemerintah kota, pengelola angkutan umum, dan masyarakat pemakai sama-sama mendapat manfaat. Agung priyambada dan savitri soegijoko sama-sama menyoroti keberadaan pedagang kaki lima (PKL). Agung menyarikan kasus-kasus yang berkaitan dengan PKL untuk memberikan gambaran secara nyata tentang permasalahan maupun potensi dari keberadaan PKL. Tidak luput dari sorotan Agung adalah sikap yang banyak diambil oleh pemerintah kota dalam menghadapi dilema ini, yang umumnya lebih menekankan pada penegakan hukum secara tidak konsisten dan kurangnya pembinaan atau pendekatan yang manusiawi.

Sementara itu, savitri menyarikan hasil penelitiannya terhadap sistem sub-kontrak di kalangan PKL di kawasan Malioboro, Yogyakarta. Ternyata, sistem sub-kontrak yang dalam beberapa hal mengkaitkan sektor informal dengan sektor formal dapat memberikan manfaat yang sangat luas bagi kedua belah pihak dan bahkan menimbulkan multiplier-effects yang positif bagi pertumbuhan ekonomi lokal. Yang mungkin harus diwaspadai dalam hal ini - dan ini tidak secara khusus disoroti dalam penelitian Savitri adalah kemungkinan adanya eksploitasi dalam sistem subkontrak.

Melalui catatan-catatan di atas. Penulis ingin mencoba memberikan konstribusi dalam diskursus tentang informal sektor di perkotaan yang sejak krisis ekonomi kembali menyeruak setelah sekian lama terdesak oleh isu-isu perkotaan lainnya, 
masalah perkotaan di Indonesia tidak akan dapat dihadapi dengan tuntas tanpa adanya pengakuan yang nyata dan perhatian yang sungguh-sungguh terhadap sektor informal.

\section{Gambaran Sektor Informal dì Kota- kota Eesar}

Kota Jakarta pada umumnya, diserbu bukan oleh kelompok bersenjata atau bukan oleh pendukung fanatisme partai politik tertentu dan juga bukan oleh kelompok yang menamakan dirinya reformis radikal. Jakarta diserbu oleh orang-orang kelaparan dan kesusuahan cari nafkah. Beberapa pengamat menuturkan kalau situasi Jakarta sekarang cukkup berbeda dibanding tahun 1995. Saat itu kalau orang- mau menyeberang di jalan protokol masih lihatlihat apakah polisi ada atau tidak. Dan para pedagang kaki lima atau asongan masih lumayan tertib. Sekarang di mana-maria semrawut, pedagang kaki lima tumpah ruah, pengemis di mana-mana, pengamen tidak hentinya serta pejalan kaki dan pengguna lalu lintas lainnya sangat tidak disiplin.

Selain masalah tertib lalulintas yang memang dari dulu cukup semrawut, masalah serius yang dihadapi kota-kota utama adalah pembenahan sektor informal. Rasanya tidak perlu dipersoalkan lagi bahwa sektor informal berperan penting dalam pembangunan ekonomi nasional. Mengacu pada data Biro Statistik, sektor informal menyumbang sekitar 74 persen terhadap kesempatan kerja pada tahun 1985 , berkurang menjadi 72 persen pada tahun 1990 dan 65 persen pada 1998. Pengurangan ini sangat kecil, artinya sektor informal merupakan penampung angkatan kerja dominan. Bahkan pasca krisis ekonomi, diperkirakan penyerapan tenaga kerja di sektor ini meningkat. Akan tetapi, meski perannya penting, pembicaraan tentang sektor informal tampak lebih menimbulkan persoalan daripada memecahkannya. Hal ini terjadi terutama karena langkanya definisi yang tepat tentang sektor informal.

Secara sederhana, konsep ini digunakan untuk merangkum segala kegiatan yang tidak termasuk dalam sektor formal, yaitu sektor yang telah terorganisir, terdaftar dan dilindungi hukum. Pengertian lain dikembangkan dari karakteristik pelakunya, umumnya yang terlibat pada sektor ini berpendidikan rendah, miskin, tidak terampil dan kebanyakan para migran. Karena itu, cakrawala mereka terbatas untuk mencari kesempatan kerja dan menghasilkan pendapatan langsung bagi dirinya sendiri, tidak untuk maksimasi profit. Meskipun demikian harus diakui banyak diantara pelaku sektor informal berusaha dan berhasil mengatasi berbagai masalah dan hambatan yang ada dan secara perlahan masuk ke dalam sektor formal.

Mengingat kapasitas sektor formal dalam menampung pertambahan angkatan kerja sangat terbatas, maka perhatian serius terhadap sektor informal sangat diperlukan. Sebenamya, departemen Tenaga Kerja telah mengembangkan kebijakan pembinaan sektor informal dengan empat pendekatan, yaitu mendorong usaha informal menjadi usaha formal, miningkatkan kemampuan usaha sektor informal yang sama, merencanakan lokasi baru bagi usaha sektor informal yang menimbuikan kerugian sosial dan mengalihkan usaha yang kurang memiliki prospek ke bidang usaha lain yang lebih prospektif.

Secara umum, program-program tersebut cenderung membantu sektor informal dari segi manajemen dan permodalan. Pendekatan ini tampaknya tidak selalu berhasil dan lebih tepat bila ditujukan pada program pengembangan usaha kecil formal 
(small scale business). Hal ini disebabkan, selain permodalan masalah utama pada informal adalah rendahnya tingkat ketrampilan dan pendidikan para pelakunya.

Jika ketrampilan merupakan cerminan. kasar dari tingkat pendidikan, sebagai gambaran, pada tahun 1998, sekitar 82 persen pekerja di sektor informal berpendidikan SD ke bawah, SLTP 11.6 persen, SLTA 6.2 persen dan diploma/Universitas 0.2 persen. Kondisi yang demikian menyebabkan - rendahnya tingkat produktivitas, sehingga pada dasarnya pertambahan kesempatan kerja baru di sektor informal tidak dapat meningkatkan produktivitas. Masalah lain menyangkut pendekatan pembinaan yang kurang didukung penataan aturan-aturan untuk melindungi sektor informal. Hal ini menimbulkan kesulitan terhadap pemerintah daiam membina sektor informal, sebab tidak sedikit di kalangan sektor informal yang pesimistis dan skeptis dengan setiap program pembinaan dan pengembangan yang diprakarsai pemerintah.

Mengingat hal tersebut, perlu kiranya dibedakan unit-unit sektor informal dengan usaha kecil karena akan berimplikasi operasional. Umumnya, usaha kecil cenderung berorientasi keuntungan dan sudah didukung keterampilan yang memadai. Masalah dihadapi pengusaha kecil lebih condong pada peningkatan kemampuan manajerial dan peluang lebih besar dalam mendapatkan dukungan permodalan. Perbedaan karakteristik ini mengisyaratkan bahwa pola pendekatan untuk membantu sektor informal haruslah berbeda dengan usaha kecil. Program pengembangan usaha kecil lebih mengarah pada pembinaan manajemen usaha dan pemberian kemudahan mendapatkan kredit modal kerja/perluasan usaha. Sedangkan crientasi pembinaan unit-unit sektor infor- mal yang tidak tergolong usaha formal kecil adalah pada peningkatan keterampilan, pendidikan dan penataan performa usaha.

Ciri-ciri pekerja sektor informal juga menunjukkan bahwa mereka tidak selalu dapat mengartikulasikan dan menetapkan kebutuhannya. Dalam hal ini perlu dicatat, meskipun berbagai usaha telah dilakukan pada waktu lalu untuk membantu sektor ini, usaha ini tidak selalu sesuai dengan harapan, misalnya seperti operasi Hari Esok Penuh Harapan (HEPH) yang dicanangkan pemerintah pada awal tahun 90-an. Kelemahan-kelemahan ini sebagian disebabkan oleh fokus yang kurang jelas terhadap kebutuhan dan kegagalan dalam menilai kemampuan unit-unit sektor informal untuk menyerap bantuan.

Dengan kata lain, tidak seperti pada program pengembangan usaha kecil, program yang ditujukan pada sektor informal harus dapat menciptakan kepercayaan, membantu mereka dalam menetapkan kebutuhannya atas berbagai-bentuk bantuan, mengetahui hubungan antara berbagai bentuk bantuan dan menilai kemampuan mereka untuk menyerap bantuan. Disisi lain, meskipun pekerjaan sektor informal membutuhkan berbagai bentuk bantuan, tipis harapan mereka akan mendapatkannya. Hal ini disebabkan, banyak kalangan mencurigai kemauan baik atau menyangsikan kemampuan pemerintah daerah untuk membantu mereka. Tidak mengherankan apabila kebijakan-kebijakan umum terhadap sektor ini di berbagai negara malah "dimusuhi" sehingga mengurangi kredibilitas program, seperti operasi HEPH.

Tampaknya penting untuk memulihkan keadaan ini melalui perubahan dalam kebijakan-kebijakan dan sikap pemerintah. Dalam hal ini, lembaga-lembaga sukarela atau LSM dapat memainkan peranan positif 
yang berguna membantu sektor informal. Pendekatan tersebut diperlukan agar dapat mengidentifikasikan berbagai bentuk bantuan, misalnya: kredit, ketrampilan, perałatan, teknologi pemasaran, prasarana dan memberikan paket yang disesuaikan dengan kebutuhan-kebutuhan mereka. Banyak negara berkembang telah menerapkan kebijakan dan pendekatan baru dalam pengembangan sektor informal.

Pemerintah Ghana misalnya, menerapkan kebijaksanaan bantuan khusus seperti penyediaan tempat atau kios untuk membangun kinerja unit-unit sektor informal yang lebih baik. India benusaha meningkatkan kreditmelalui program-program khusus untuk golongan lemah dan sektor informal, serta mengembangkan kemudahan dalam pemasaran. Sedangkan Filipina berusaha memberikan ketrampilan sebagai suatu sarana untuk mobilitas pekerjaan. Sudah sangat diperlukan reorientasi pembinaan yang mengacu pada peningkatan keterampilan, penataan performa usaha dan wilayah pemasaran. Selain itu, perlu adanya penataan aturan yang seimbang untuk menghindarkan perlakuan yang sewenangwenang terhadap pelaku sektor informal dan sekaligus untuk menghindari kota dari kesernrawutan. Bagaimanapun, sektor informal yang tidak terkendali akan cenderung menyebabkan ketidak tertiban kota.

Sekarang ini semua serba budget tidak ada. Kalau ada rekomendasi program untuk peningkatan keterampilan sektor informal, yang keluar ada koor: budget dari mana? Kenyataannya, sekitar 23 anggota DPRD Jabar tur wisata ke Australia untuk menghabiskan sisa budget. Ini adalah yang terungkap dan setidaknya banyak hal-hal yang tidak terungkap. Jadi persoalannya bukan ada budget atau tidak, tetapi apakah pemerintah daerah punya komitmen untuk membenahi sektor informal.
Peningkatan ketrampilan tidak harus memerlukan biaya sangat tinggi karena itu bisa dilakukan secara kerjasama dengan lembaga non profit. Hal yang sama juga untuk penataan performa usaha, lembaga non profit yang memiliki kapasitas di bidang ini dapat diajak kerjasama dengan Pemda. Kerjasama anatara pemda dan lembaga non profit ini akan bermanfaat ganda, yakni selain bisa menekan biaya juga membuat program berjalan lebih efektif karena pelaku sektor informal umumnya masih respek terhadap lembaga-lembaga non profit dibanding kepada pemerintah daerah. Krisis sekarang telah membuat pemerintah daerah dan pusat memiliki banyak excuse untuk lebih santai dan kurang terfokus. Lebih memilih pasif dari pada aktif dan lebih memilih berkelit daripada berbuat, termasuk dalam membenahi sektor informal. Mudah-mudahan kelalaian ini tidak samapi berkembang menjadi parah. Kalu tidak, kita hanya bisa melihat kota-kota yang super semrawut dan tidak aman.

\section{Marginalisasi Sektor Informal}

- Masalah penertiban dan tata ruang, tampaknya senantiasa menjadi masalah pelik yang sering terjadi di berbagai kawasan urban, termasuk kota Surabaya. Masalah tersebut biasanya melibatkan beberapa pihak yang berselisih. Pertama, pihak pengelola pasar, dalam hal ini PD pasar Surya. Kedua, Pemkot Surabaya yang berkepentingan dengan tata ruang dan keindahan kota. Dengan demikian, ambisi untuk menciptakan kota yang bersih, indah dan tertib sesuai prasyarat kota metropolitan diharapkan mampu menarik investasi dalam jumlah besar dari para investor high class. Wujud kongkritnya bisa berupa bangunan-bangunan gedung bertingkat, seperti apartemen mewah, hotel berbintang, dan pasar modern dari perusahaanperusahaan raksasa. Misalnya, 'Giant 
Hypermarket, Carrefour, Pakuwon, dan Plaza-plaza yang kini menjamur di bebrapa. kawasan kota.

Sementara itu, pihak lain, yakni kelompok masyarakat kecil urban yang menggeluti usaha di sektor-sektor informal seperti pedagang kakilima ( $\mathrm{PKL}$ ), pedagang loak, dan sayur mayur di pasar-pasar tradisional sering dihantui was-was akan adanya penertiban serta penggusuran dari pihakelite pemkot. Mereka sering distikmakan. sebagai pihakyang memperburuk keindahan kota, menimbulkan kemacetan, dan stigma negatif lain yang cenderung memosisikan mereka sebagai kelompok marginal yang harus ditertibkan(kasarannya disingkirkan dari kawasan urban).

Masalahnya barangkali bukan hanya bertumpu pada soal kelas seperti yang pemah dikatakan Karl Marx, yakni kelas proletar sering menjadi basis eksploitasi kelas kapitalis dan elite penguasa, melainkan berkaitan dengan bebrapa masalah krusial yang perlu diperhatikan. Pertama: menyangkut kebijakan elite lokal tentang tata ruang kota, Penertiban, penggusuran, atau relokasi yang telah dilakukan selama ini tidak diikuti kebijakan strategis yang menguntungkan dan berpihak pada para pedagang kaki lima atau kaki lima (PKL).

Umumnya, kebijakan relokasi atau penertiban hanya menyediakan lokasi tanpa mempertimbangkan apakah lokasi itu strategis dan menguntungkan bagi para pedagang dalam meningkatkan usahanya atau tidak. Strategis dalam arti lokasi atau tempat usaha yang baru tersebut mampu menyerap perhatian dan daya tarik masyarakat (konsumen). Karena itu, perlu dipertimbangkan secara matang daerah mana saja yang cukup strategis ketika pemkot berencana merelokasi pasar loak ke daerah Bangkalan, mengingat letaknya yang relatif jauh (sekitar $20 \mathrm{~km}$ ) dari pusat keramaian kota. Untuk kepentingan tersebut, penting kiranya Pemkot Surabaya bekerja sama dengan pemkot Bangkalan mengidentifikasi secara dini dengan mensurvei lapangan guna pemetaan potensi wilayah. Jika perlu, disertai dengan analisis masalah dampak lingkungan (amdal).

Kedua, para pengamibil keputusan atau kebijakan seharusnya menyadari nasib dan masa depan pedagang. Mereka berupaya keras mengadu nasib dengan berwirausaha di sektor informal. Sektor-sektor informal seperti PKL dan pedagang loak adalah kaum miskin kota yang sebetulnya tidak hanya berperan untuk menghidupi keluarganya, tapi juga sebagai tulang punggung perekonomian masyarakat urban. Bahkan menurut pakar sosiologi perkotaan DE Soto (1991), sektor informal mampu menjadi katup penyelamat ekonomi perkotaan dengan penciptaan lapangan kerja. Mengingat tingginya pengangguran di perkotaan, baik akibat sulitnya mendapatkan pekerjaan maupun PHK, sektor informal menjadi solusi altematif bagi terbukanya peluang usaha yang bermodal kecil tapi padat karya.

Dengan demikian, pemkot sepatutnya merespons positif dengan memberikan peluang, akses, sarana, dan prasarana yang sebaik-baiknya bagi tumbuh kembangnya sektor informal di kawasan urban tanpa harus menertibkan dan memindahkan mereka ke wilayah-wilayah yang relatif sepi, bahkan menggusur paksa. Dalam konteks ini, kalaupun penertiban dan relokasi tetap menjadi prioritas kebijakan yang harus terlaksana, perlu ada ruang dialog pengambil kebijakan, baik di tingkat eksekutif maupun legislatif, dengan para pedagang loak serta PKL guna mencapai titik temu dan kesepakatan antar kedua pihak. Hal itu sekaligus menjadi media 
sosialisasi dan transparansi kebijakankebijakan pemkot kepada publik, terutama di tingkat grass roots yang berkaitan dengan tata ruang dan master plan kota Surabaya.

Membangun kota metropolitan yang humanis memang menjadi ambisi besar kota-kota. Bagi kota Surabaya yang dianggap kota terbesar setelah Jakarta, metropolitanisasi tersebut bukan tanpa beban. Apalagi, perusahaan itu harus berhadapan dengan berbagai kepentingan untuk menata ruang dalam rangka memberikan tempat bagi aktivitas ekonomi bersekala besar dan global sering harus berhadapan dengan kepentingan ekonomi bersekala kecil lapisan bawah masyarakat kota yang tradisional. Menurut John Silas (1996), ruang gerak lapisan ekonomi bersekala kecil itu merupakan lapisan yang harus tersingkir akibat penataan ruang yang ingin memberikan tempat bagi kepentingan ekonomi berskala besar dan global tersebut. Semua itu memang merupakan harga yang harus dibayar untuk menjadikan Surabaya sebuah metropolitan baru

Karena itu, dubutuhkan cara pandang yang multidemensional dalam melihat masalah-masalah kota dalam rangka menuju metropolitan tersebut. Hal itu tentu bukan pekerjaan mudah karena melibatkan berbagai aspek dimensional yang luas cakupannya. Paradigma tentang tata ruang yang layak huni dan menampilkan wajah kota yang humanis (manusiawi) dari aspek ekologi, sosial, budaya, politik, dan ekonomi menjadi agenda utama serta mendesak untuk dikaji secara serius, terutama oleh para pengambil kebijakan (termasuk pemkot dan DPRD) setempat serta barbagai lapisan masyarakat. Karena itu, sebelum terlambat, hal tersebut perlù dilakukan sebagai upaya preventif munculnya problem banyang lebih besar di kemudian hari.
Tentu, dalam banyak hal, dibutuhkan ruang publik yang sinergis antara para pengambil kebijakan (decision makers) dan masyarakat kota dalam menentukan pengembanmgan serta pembangunan kota tersebut. Dengan begitu, terjadi hubungan timbal balik yang saling menguntungkan antara kedua belah pihak. Implikasinya akan berpengaruh pada keseimbangan dan stabilitas sistem yang mengarah pembangunan (tatà ruang) kota yang teratur, bersih, dan tidakmengorbankan kelompokkelompok miskin kota yang mayoritas. Dengan demikian, kesadaran semua pihak menjadi faktor penentu dalam membangun Surabaya menuju kota metropolitan baru yang lebih humanis, bersih, serta teratur.

\section{Sektor Informal dibidang Konstruksi}

Salah satu yang akhir-akhir ini banyak mendapat perhatian dari para ahli maupun dari aparat pembuat kebijakan adalah bagaimana meningkatkan peranan sektor informal ini khususnya dalam jasa konstruksi guna mendukung pembangunan perumahan. Masalah ini cukup mendesak, mengingat belum ada satu negarapun dibumi ini yang dapat menuntaskan problema penumahan bagi warga negaranya. Di Indonesia, di mana hampir-85\% pengadaan perumahan itu dilakukan lewat masyarakat sendiri (based on community), maka sudahlah sewajarnya kalau sektor informal ini mendapat dukungan dari berbagai pihak dalam kehadirannya pada berbagai sudut-sudut kota ini sekaligus meramaikan nuansa pembangunan kota.

Demikian pula dengan hasil pekerjaannya yang kurang dapat dihargai khalayak banyak, karena lagi-lagi atribut "informal" yang disandangnya maka meskipun produk mereka dapat ditingkatkan, tetapi 
sulit untuk masuk dalam pasar yang "formal".

\section{Keseimbangan Lingkungan Kumuh dan Pembangunan}

Kehadiran sektor informal sebenarnya memberikan kontribusi positif dalam perkembangan ekonomi lokal kota. Meskipun demikian, sektor informal memiliki peranan yang cukup signifikan dalam menunjang kehidupan sehari-hari, namun keberadaannya sangat rentan dan selalu menambah kekumuhan kota sepanjang tidak ada penataan dan aturan yang tegas atau kesadaran sektor informal untuk mengatur diri sendiri. Sebagai akibat dari kerentanan sektor informal kebanyakan migran dari pedesaan yang mencoba mengadu nasib di perkotaan dan bekerja di sektor informal, rata-rata kesulitan untuk melepaskan diri dari himpitan ekonomi. Mereka yang telah terjebak dalam sektor informal selalu kesulitan untuk melepaskan diri dari atribut masyarakat miskin yang dialami sebelumnya ketika tinggal di desa. Upaya yang diperlukan untuk mengatasi kekumuhan akibat migran desa yang lemah potensi mendasar ini adalah dengan saling pemberdayaan sumberdaya manusia yang berorientasi pada peluang usaha dan kesempatan kerja. Upaya lain, dengan kebijakan urbanisasi yang diarahkan pada pengembangan daerah pedesaan agar memiliki ciri perkotaan atau urbanisasi pedesaan; disamping perlu dikembangkan pusat pertumbuhan ekonomi baru atau daerah penyangga pusat pertumbuhan yang berfungsi sebagai penapis bagi perpindahan penduduk.

\section{Keterpaduan Penanganan}

Penanganan Lingkungan kumuh yang tak serius dan terpadu-memberikan keabsahan pada terjadinya sindroma Pareto dalam penanganan kumuh di kota. Sindroma ini mengacu hukum Pareto yang menyatakan kelompok menengah atas dan kelompok atas di kota jumlahnya sekitar 20 persen, dilayani oleh 80 persen fasilitas kota yang terbaik, sementara sisanya 20 persen fasilitas yang terbaik di kota harus dibagi oleh 80 persen kelompok masyarakat yang kondisi ekonominya pas-pasan dan kurang mampu.

Pendekatannya berpegang pada kearifan lokal dalam mengatasi permasalahan kesejahteraan dengan peluang usaha dan kesempatan kerja, disamping program penanganan kawasan kumuh lebih serius dan terpadu agar sesuai dengan aspirasi, kebutuhan dan kompetensi lokal. Adanya program peremajaan kampung atau dengan program perbaikan kampung, program rumah susun sewa, bahkan dapat dilakukan dengan program penyuluhan terpadu maupun program saling pemberdayaan masyarakat agar masyarakat dapat mengatur, melayani dan meningkatkan kualitas lingkungan perumahannya sendiri. Model dana bergulir untuk perbaikan fisik di lingkungan perumahan semakin menjadi beban berat saja tanpa dipecahkan solusi peningkatan pendapatan berdasar potensi lokal. Keterlibatan masyarakat sejak awal bukannya untuk membebani yang miskin tambah miskin karena kesalahan dalam pengertian partisipasi dan keharusan masyarakat untukberswadaya. Pengelolaan potensi dan kompetensi lokal secara partsipatoris, inklusif, demokratis dan berkelanjutan adalah menjadi tujuan utama penanganan lingkungan kumuh kota. Untuk itu diperlukan kemitraan yang melibatkan berbagai unsur pemerintah, NGO, dunia usaha, perguruan tinggi dan masyarakat. Upaya -ini harus dibarengi dengan penyediaan pelayanan sosial yang 
memadai, sesuai reposisi pencapaian Millenium Development Goals pada event hari Habitat 2005 sasarannya pemukiman kumuh, Air Minum, Sanitasi dan Infrastruktur Perkotaan.

Penanganan yang lebih terencana, terarah, manusiawi, serius dan terpadu inilah yang diyakini dapat secara berangsur-angsur menyelesaikan masalah lingkungan kumuh kota. Konsep Guided Land Development (GLD) mengusahakan agar penanganan kumuh dengan pengembangan tata ruang wilayah yang sedang dan akan berkembang diarahkan melalui pola infrastruktur yang lebih terencana dan terpadu dengan melibatkan masyarakat setempat dalam perencanaan wilayah. Penanganan kumuh melalui program perbaikan kampung agar lebih komperhensip dengan pendekatan terpadu. Kekumuhan kota yang dikarenakan ketidak mampuan dari segi ekonomi dan pendidikan, dilakukan dengan saling pemberdayaan ekonomi agar lebih banyak peluang usaha dan kesempatan kerja. Partisipasi masyarakat lokal di lingkungan kumuh dalam kegiatan investasi sangat perlu diperhatikan dengan memakai insentif fiskal dan nonfiskal yang tidak distortif. Keterlibatan masyarakat lokal juga dapat dilakukan dengan mendorong masyarakat merebut peluang-peluang yang timbul sebagai akibat "muitipler" effects suatu investasi (trckle-up effect). Tanpa ada keseriusan dan keterpaduan penanganan lingkungan kumuh kota secara arif lokal, tidak akan tuntas menyelesaikan permasalahan utama mengangkat taraf kesejahteraan.

Keseriusan penanganan perlu secara menyeluruh dan total. Oleh karena itu perlu keterpaduan penanganan lingkungan kumuh yang mempunyaii implikasi efisiensi dan efektifitas dalam pola pendanaan, materi penanganan, lokasi kumuh; waktu penanganan yang tepat sesuai kebutuhan masyarakat. Pola penanganan lingkungan kumuh yang serius dan terpadu ditawarkan dengan tiga modul utama, yaitu adanya kelembagaan yang baik, keterbukaan dan partisipasi masyarakat yang makin menyatu. Kelembagaan yang menangani lingkungan perumahan perlu dibenahi dan diperjelas peran dari ketugasannya agar lebih efektif, tidak terjadi tumpang tindih. Gejala ketidak seriusan ada bila segala program penanganan kumuh kota tidak serius dan terpadu di lapangan dikarenakan masingmasing pelaku pembangunan punya kegiatan serta lokasi kumuh yang ditangani. Dengan demikian pengembangan kelembagaan koordinasi, pembinaan dan pengendalian menjadi urgen untuk mendapat supporting dana serta perhatian khusus dan bentuk badan di lokasi kumuh. Keterbukaan menjadi penting dengan melibatkan unsur perguruan tinggi, LSM, dan jaringan masyarakat kota, agar mampu memberi masukan subtantif terhadap pelaksanaan penanganan kumuh kota. Melalui keterbukaan dapat menggalang partisipasi másyarakat tingkat tinggi yaitu kewenangan masyarakat jelas akan lebih menonjol dan memutuskan.

Pendekatan penataan kumuh dengan peningkatan mutu kehidupan secara kualitatif, menarik untuk dikaji karena terkandung dinamika peningkatan mutu dalam suatu perubahan lingkungan perumahan yang seimbang. Meskipun akạn muncul tantangan maupun kendala yang menghadang adanya kondisi keseimbangan lingkungan perumahan yang mengalami akselerasi peningkatan secara kualitatif, tentu berupa peningkatan mutu hidup dan kualitas lingkungan perumahan melalui daya kreasi manusia dan daya dukung yang lestari. Faktor pendukung yang menjadi pemikiran aspirasi masyarakat yang 
sederhana adalah adanya kondisi biofisikal yang membatasi pertumbuhan ekonomi, dan faktor kondisi etika sosial yang mambatasi hasrat pertumbuhan disetiap kampung kumuh.

Pelibatan masyarakat setempat penting, eksesnya masyarakat yang akan menanggung resiko dan perubahan bangunan fisik sarana dan prasarana terbangun untuk disesuaikan dengan perilaku dan kebiasaan masyarakat.

\section{Penutup}

Pemerintah seharusnya harus bersikap arif terhadap munculnya sektor informal, karena sebetulnya sektor informal juga membantu pemerintah untuk memasukkan pendapatan daerah, kalau mungkin bagaimana sektor informal ini juga diberi kemudahan-kemudahan dalam mendapatkan fasilitas pemerintah atau mendapatkan kemudahan kredit dan bunga yang ringan.

Aspirasi masyarakat bawah hendaknya diperhatikan, karena kelompok ini adalah masyarakat yang berkembang menginginkan rakyatlah sebagai perientu utama perencanaan, pelaksanaan dan pengontrol penataan kempungnya sendiri. Pelestarian ciri khas dan keunikan kampung dapat terangkat dengan memberikan tempat secara hukum tentang status hunian dan usahanya kepada semua penghuni, terlepas dari latar belakang sosial menghormati hak ekonomi dan budaya sebagai upaya mengembalikan kedaulatan rakyat dalam menata ruang hidupnya.

Keterpaduan penanganan lingkungan kumuh mempunyai implikasi efisiensi dan efektifitas dalam pola pendanaan, materi, penanganan, lokasi-kumuh, waktu penanganan yang tepat sesuai kebutuhan masyarakat. Pola penanganan lingkungan kumuh yang serius dan terpadu ditawarkan dengan tiga modal utama, yaitu: adanya kelembagaan yang baik, keterbukaan, dan partisipasi masyarakat yang makin menyatu.

\section{Daftar Pustaka}

Badan Pusat Statistik, Bapenas, UNDP 2004. The Economic of Democracy. Finacing Human Development in Indonesia. Jakarta: BPS

Kelly, Philip F. 1999, Everyday Urbanization: The Social Dynamics of Development in Manila's Extended Metropolitan Region, International Joumal of Urban Regional Research, 23(2): 283303.

Magister Sistem dan Teknik Transportasi UGM, Studi Kelayakan Reformasi Sistem Transportasi Angkutan Umum Perkotaan Di Propinsi DIY, Laporan Akhir, Desember 2005.

Sarosa, Wicaksono, 2000, Pengantar: MenyorotiSektorinformal Perkotaan, "Research and Development Director Urban and Regional Development Institute (URDI)"

Tobing, Elwin, 2002, Reorientasi Pembenahan Sektor Informal, dari http//www.theindonesianinstitute.org/ daily22002.htm

Winarno, Doso, 2005, Menyongsong Hari Habitat Sedunia 2005, dari http:// www.pemda-diy.go.id/berita/ modphn?mod=userpage\&page_id $=1375$ \&menu= 